the controls. These experiments indicated that some of these patients have hyperfunction of adrenocortical glands.

3) The removal rate of the infused cortisol from the plasma was much protracted in some of these patients with higher plasma cortisol leves. Amounts of excreted urinary 17-OH-corticosterone generally decreased in all of the patients above mentioned. These experiments suggest that the reduction of cortisol to tetra types is impaired in these patients.

\title{
Studies on the Thyroid Diseases (The 1st Report)
}

\author{
Adrenocortical Function in the Thyroid Diseases
}

\author{
By
}

\section{Yoshiharu KITAGAWA}

The 2nd Department of Internal Medicine, School of Medicine, Hokkaido University

(Director : Prof. T. Torii)

The author studied statistically the correlation between adrenocortical function and thyroid function in patients with hyperthyroidism, hypothyroidism and in normal subjects.

For this purpose, BMR, PBI and $\mathrm{I}^{131}$ uptake of thyroid gland were measured as indices of the thyroid function, on the other hand urinary total 17-OHCS, 17-KS and circulating eosinophiles before and after ACTH test (drip infusion of 20 I.U. ACTH in 6 hours) were measured as indices of the adrenocortical function.

The results were as follows :

1) There was significant correlation between $B M R$ and urinary total $17-\mathrm{OHCS}$ ( $\mathrm{N}=44, \mathrm{r}=0.61$, $\mathrm{p}<0.01)$ and also between BMR and urinary $17-\mathrm{KS}(\mathrm{N}=44, \mathrm{r}=0.45, \mathrm{P}<0.01)$

2) There was significant correlation between $\mathrm{PBI}$ and urinary total 17-OHCS $(\mathrm{N}=44, \mathrm{r}=0.49, \mathrm{p}<$ 0.01), and also between PBI and urinary 17-KS $(\mathrm{N}=44, \mathrm{r}=0.51, \mathrm{p}<0.01)$

3) No correlation was found between $I^{131}$ uptake of thyroid gland (after 24 hours) and urinary total 17-OHCS ( $N=32, r=0.24)$, whereas $I^{131}$ uptake was correlated to urinary $17-\mathrm{KS}(\mathrm{N}=32, \mathrm{r}=0.59$, $\mathrm{p}<0.01)$

4) The output of urinary total 17-OHCS after ACTH test did not show any significant difference between hyperthyroid, hypothyroid and euthyroid patients. In female subjects no significant difference was found in three groups, whereas in male subjects urinary 17-KS in thyroid diseases either hyper or hypothyroidism was lower than euthyroid subjects without thyroid disease.

5) No correlation was found between eosinopenic index after ACTH test and BMR or PBI. 


\title{
甲状腺疾患に関する研究（第 1 報）
}

\author{
甲状腺疾患に和ける副腎皮質機能
}

\author{
北海道大学医学部第二内科 (主任 鳥居敏雄教授)
}

北 川 吉 春

\begin{abstract}
緒言
甲状腺疾患における副堅皮質機能について今まで多くの報告がすられるが，研究者により見解は必ずしも 一致していない.

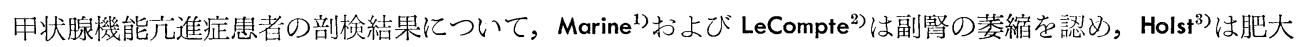
を認め，Means $\left.{ }^{4}\right)$ は全く変化を認めていない，甲状腺機能低下症例ではBerkheiser ${ }^{5)}$ は副腎の萎縮を報告してい る.
\end{abstract}

甲状腺疾患患者の副等皮質ステロイドの測定結果の報告では, 血中遊離 17-Hydroxycorticosteroid(以下17-

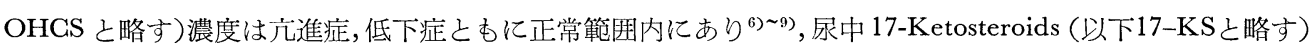

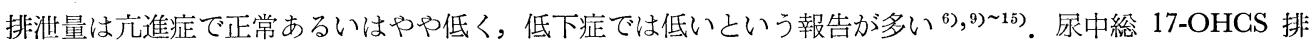

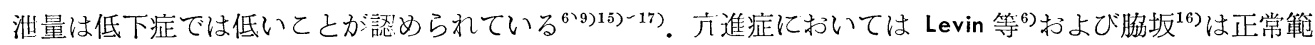
团内にあり，鳥飼 ${ }^{15}$ はやや高いと報告している。しかし Brown 等 ${ }^{17}$ は圥進症では尿中 17-OHCS 排泄量が

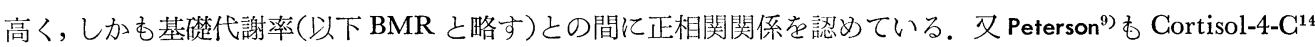
を用いてその半減期および Turn-over rate より計算して，充進症では副腎からの内因性 17-OHCS の分泌 が高まり，尿中総 17-OHCS 排泄量の増加することを明らかにした.

臨床的には甲状腺機能充進症の極期の場合には屡々副婜皮啠機能不全と似た症状を呈する。既に1921 年 Shapiro 等 ${ }^{13)}$ は光進症㭧者に新鮮副掔を投与して症状の軽快した例を報告している，その後も重症甲状腺中毒 症に対し，副腎皮質ホルモンあるいは ACTH を投与して症状の軽快した例が多く報告されている ${ }^{1) 920021)}$. Mikulai 等 ${ }^{22}$ は甲状腺機能充進症と正常人の ACTH 試験による血中 17-OHCS 濃度の変化を観察し，大量 の ACTH の注射では充進症は正常人に比し反応が鈍いと述べている.

実験的に甲状腺末あるいは甲状腺ホルモンを動物に投与すると，副婜の肥大をきたすといわれている ${ }^{23 ~ 26)}$. Levin 等6) はモルモットに Thyroxine を注射し代謝率の増加に伴つて尿中遊離 17-OHCS 排泄量の增加する ことを認めた，又甲状腺剔出あるいは抗甲状腺剤の投与により副腎の萎縮をきたすといわれる2627).

甲状腺ホルモンと副婜皮質ホルモンとの相互関係について，副腎皮質ホルモンあるいは AGTH が甲状腺 ホルモンの分泌を抑制するととは以前より認められている ${ }^{28 \sim 30)}$ 。一方甲状腺ホルモンは, 研究者により意見 の一致しない点も残されているが，最近では副婜皮質ホルモンの分泌を促進するという報告が多い．著者等 は臨床例についてての問題を研究し，甲状腺ホルモンが副婜皮質ホルモンの分泌を促進するととを確かめ。 更に若干の知見を得たので報告する.

\section{被検者並びに実験方法}

昭和32年春以降入院した Basedow 氏病患者，男 11 例，女12例，計23例，粘液水腫患者，男 2 例，女 6 例， 計 8 例, 内分泌学的に正常之認妨られた男 5 例, 女 8 例, 計13例を被検者とした. 診断は臨床症状おょび $\mathrm{BMR}$, 血漿蛋白結合沃度 (以下 PBI と略す)，甲状腺 $\mathrm{I}^{131}$ 摄取率，血清コレステロール等の測定值から確定さ れた. BMR は Benedict 型基礎代謝率計を用いて測定した. PBI は Barker アルカリ灭化法 ${ }^{31}$ の日置，大

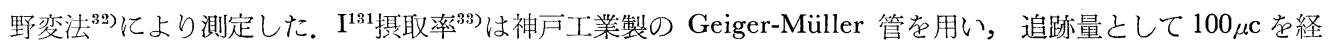
口投与し，投与後 3 時間目および24時間目に測定した。副婜皮質機能をみるため無処置時の尿中総 17- 
OHCS および 17-KS の24時間排泄量, ACTH 点静注後の未梢血液中好酸球減少率 ${ }^{34}$ および尿中17-OHCS と 17-KS の排泄量を測定した。好酸球減少率は ACTH 点滴中止後 1 時間目，2 時間目，3 時間目の 3 回 そわたり測定し最も值の高いものをとつた。尿中総 17-OHCS は Reddy, Jenkins，Thorn 法 ${ }^{35}$ )36) により測定 した.

\section{尿中 17-KS 測定法}

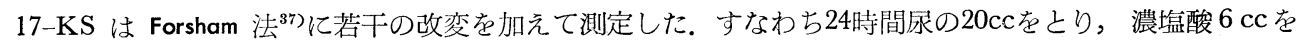
加え $80^{\prime} \mathrm{C} 30$ 分間加熱水解する. 冷却後分液漏斗を用い, エーテル $25 \mathrm{cc}$ で 2 回，各 5 分間振つて抽出する. 工 一テル抽出液を合し，苛性ソータ，八イドロサルファイト混液 $\left(\mathrm{NaOH} 10 \mathrm{~g}\right.$ と $\mathrm{Na}_{2} \mathrm{~S}_{2} \mathrm{O}_{4} 10 \mathrm{~g}$ を蒸溜水に之か して100ccとする) $10 \mathrm{cc}$ で 2 回，各 1 分間，更に蒸溜水 $10 \mathrm{cc}$ で 3 回，各 1 分間振つて洗涤する．洗滌したエ・. テル抽出液を $10 \mathrm{cc}$ 宛 2 本とり蒸発乾燥する。 下記の試薬を加えよく振つて混ぜる.

(1) 乾燥残渣十無水エタノール0.2cc $+1 \%$ m-Dinitrobenzen(以下 m.d.b. と略す)エタノール溶液 $0.2 \mathrm{cc}$ $+2.5 \mathrm{~N}-\mathrm{KOH} x$ タノール溶液(以下 $\mathrm{KOH}$ 液と略す) $0.2 \mathrm{cc}$.

第 1 表 BMRと尿中 17-OHCS，17-KS排泄量

\begin{tabular}{|c|c|c|c|c|c|c|c|}
\hline & 番号 & 被検者 & 性 & $\begin{array}{l}\text { 年 } \\
\text { 令 }\end{array}$ & $\begin{array}{c}\mathrm{BMR} \\
\%\end{array}$ & $\begin{array}{c}\text { 17-OHCS } \\
\mathrm{mg}\end{array}$ & $\begin{array}{c}17-\mathrm{KS} \\
\mathrm{mg}\end{array}$ \\
\hline \multirow{9}{*}{ 機 } & 1 & 勝 & $\hat{0}$ & 34 & 28 & 8.3 & 15.5 \\
\hline & 2 & 山 $\bigcirc$ & $\ddot{q}$ & 24 & 35 & 4.2 & 11.9 \\
\hline & 3 & 山, $\bigcirc$ & 㑒 & 44 & 43 & 10.7 & 24.4 \\
\hline & 4 & 西 $\bigcirc$ & 우 & 21 & 33 & 5.0 & 7.5 \\
\hline & 5 & 古 0 & 우 & 28 & 47 & 12.5 & 18.2 \\
\hline & 6 & & $\hat{0}$ & 33 & 60 & 18.0 & 17.2 \\
\hline & 7 & & $\hat{\delta}$ & 49 & 60 & 7.2 & 12.7 \\
\hline & 8 & 名 $\bigcirc$ & 今ิ & 48 & 46 & 13.0 & 10.2 \\
\hline & 9 & & $\ddot{q}$ & 22 & 41 & 11.0 & 8.2 \\
\hline \multirow{2}{*}{ 能 } & 10 & & 우 & 44 & 57 & 15.0 & 10.0 \\
\hline & 11 & 中 $O$ & $\hat{\delta}$ & 29 & 68 & 12.0 & 19.2 \\
\hline \multirow{2}{*}{ 艺 } & 12 & 北 & 후 & 20 & 40 & 9.3 & 7.8 \\
\hline & 13 & & 우 & 20 & 58 & 4.1 & 8.5 \\
\hline \multirow{3}{*}{ 進 } & 14 & 佐々木 & $\hat{f}$ & 25 & 23 & 10.6 & 9.7 \\
\hline & 15 & 武 0 & 우 & 25 & 40 & 14.8 & 19.7 \\
\hline & 16 & & $\hat{\delta}$ & 37 & 82 & 19.6 & 15.8 \\
\hline \multirow[t]{10}{*}{ 症 } & 17 & 添 0 & 호 & 22 & 30 & 11.6 & 12.0 \\
\hline & 18 & & 우 & 45 & 27 & 12.8 & 9.8 \\
\hline & 19 & 新 $\bigcirc$ & 우 & 21 & 56 & 19.4 & 10.6 \\
\hline & 20 & 0 & 定 & 33 & 47 & 6.3 & 14.6 \\
\hline & 21 & & $\hat{\sigma}$ & 38 & 21 & 9.8 & 21.7 \\
\hline & 22 & 伊 & 芰 & 30 & 26 & 13.9 & 19.0 \\
\hline & 23 & 宍 & $\hat{o}$ & 29 & 15 & 10.8 & I \\
\hline & 1 & 都 0 & $\hat{\delta}$ & 29 & -14 & 6.8 & 16.9 \\
\hline & 2 & 黑 0 & 今 & 50 & & 6.0 & 16.2 \\
\hline & 3 & & 후 & 18 & -4 & 11.0 & 7.2 \\
\hline \multirow[t]{3}{*}{ 正 } & 4 & 兼 & 우 & 23 & -10 & 6.8 & 12.2 \\
\hline & 5 & & 후 & 24 & -4 & 5.9 & 9.2 \\
\hline & 6 & & $\hat{\jmath}$ & 35 & 16 & 9.0 & 20.1 \\
\hline \multirow[t]{3}{*}{ 常 } & 7 & 熊 $\bigcirc$ & 우 & 16 & 4 & 2.8 & 6.5 \\
\hline & 8 & 芐○内 & 今 & 49 & 10 & 6.0 & 16.5 \\
\hline & 9 & 藤 $\bigcirc$ & 우 & 46 & 5 & 14.3 & 8.1 \\
\hline \multirow[t]{5}{*}{ 人 } & 10 & 酒 & 㑒 & 56 & -8 & 8.2 & 12.4 \\
\hline & 11 & 木 & 우 & 49 & & 3.5 & 13.3 \\
\hline & 12 & 佐○木 & 우 & 24 & -7 & 5.2 & 6.6 \\
\hline & 13 & 菅 0 & io & 21 . & -7 & 2.5 & 9.5 \\
\hline & 1 & 松 & iq & 41 & -20 & 2.4 & 2.4 \\
\hline \multirow{7}{*}{ 機 } & 2 & 鐮 & 후 & 48 & -20 & 2.0 & 8.4 \\
\hline & 3 & 堀 & 우 & 29 & -8 & 8.8 & 12.5 \\
\hline & 4 & 白 & 定 & 35 & -12 & 7.2 & 9.8 \\
\hline & 5 & 西 & 定 & 29 & -15 & 9.4 & 8.2 \\
\hline & 6 & 0 & 오 & 55 & -8 & 6.4 & 3.6 \\
\hline & 7 & 水 & 우 & 53 & 5 & 5.0 & 1.3 \\
\hline & 8 & 山 & 우 & 34 & -34 & & 5.4 \\
\hline
\end{tabular}

第 1 図 BMR と17-OHCS との相閣

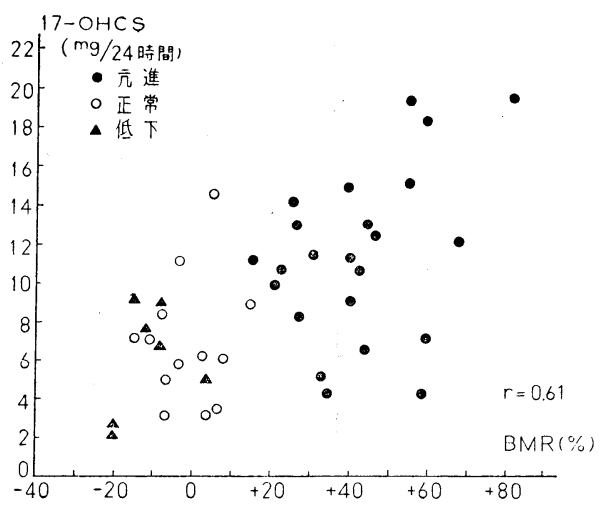

第 2 図 BMRと17-KSとの相䦥

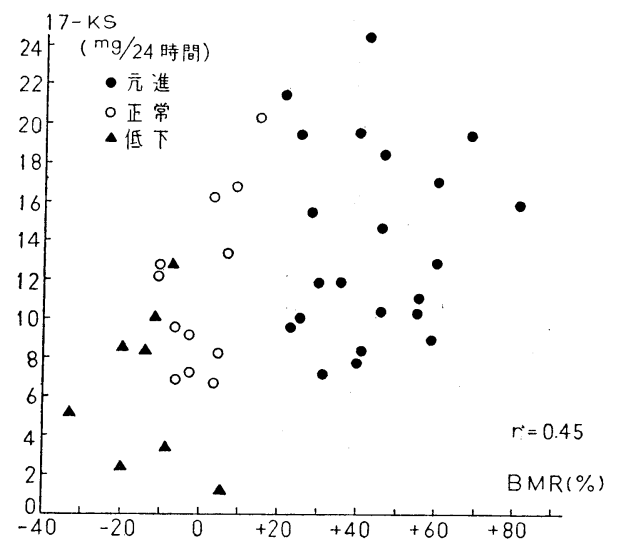


(2) 残渣 + エタノール0.4cc+ $\mathrm{KOH}$ 液 $0.2 \mathrm{cc}$.

(3) Dehydroisoandrosterone エタノール溶液 (Dehydroisoandrosterone $25 \mathrm{mg}$ を無水エタノールにとか して $100 \mathrm{cc}$ とする） $0.2 \mathrm{cc}+$ m.d.b. 液 $0.2 \mathrm{cc}+\mathrm{KOH}$ 液 $0.2 \mathrm{cc}$.

(4) 無水エタノール0.2cc + m.d.b. 液 $0.2 \mathrm{cc}+\mathrm{KOH}$ 液 $0.2 \mathrm{cc}$.

(5) 無水エタノール0.4cc+KOH 液 $0.2 \mathrm{cc}$.

以上を $25^{\circ} \mathrm{G} 105$ 分間加温して発色させ，冷却後各々に70\%エタノール4 cc を加えて稀釈し，光電比色計で (5)をブランクとして $520 \mathrm{~m} \mu て ゙$ 読み，次の計算によつて值を求める.

24 時間尿中17-KS排泄量 $=\frac{(1)-(2)-(4)}{(3)-(4)} \times 5 \times \frac{24 \text { 時間尿量 }}{20} \times 0.05 \mathrm{mg}$

AGTH 試験はAGTH20単位を $5 \%$ ブドー糖液 $1000 \mathrm{cc} に$ 加え，6時間点滴静脈内注入を行つた。 AGTHは N.V.オルガノン製で Lot 番号の同じものを全例に用いた.

甲状腺機能諸検查と副㹂皮質機能諸検査との間の相関係数を計算しそその有意性を推計学的に検定した.

第 2 表 PBI と尿中17-OHCS17-KS排泄量

\begin{tabular}{|c|c|c|c|c|c|c|c|}
\hline & 番号 & 被検者 & 性 & \begin{tabular}{l|} 
年 \\
令
\end{tabular} & $\begin{array}{l}\mathrm{PBI} \\
(\mathrm{r} / \mathrm{dl})\end{array}$ & $\begin{array}{c}\text { 17-OHCS } \\
\text { mg }\end{array}$ & $\begin{array}{c}17-\mathrm{KS} \\
\mathrm{mg}\end{array}$ \\
\hline \multirow{8}{*}{ 機 } & 1 & 勝 $\bigcirc$ & 令 & 34| & 9.6 & 8.3 & 15.5 \\
\hline & 2 & 山 & 우 & 24 & 7.0 & 4.2 & 11.9 \\
\hline & 3 & 山 & $\hat{o}$ & 44 & 9.0 & 10.7 & 24.4 \\
\hline & 4 & 西 0 & 우 & 21 & 7.6 & 5.0 & 7.5 \\
\hline & 5 & & o & 28 & 10.6 & 12.5 & 18.2 \\
\hline & 6 & 北 & 昘 & 33 & 7.4 & 18.0 & 17.2 \\
\hline & 7 & 阿 & $\hat{\delta}$ & 49 & 8.4 & 7.2 & 12.7 \\
\hline & 8 & 名 & $\hat{0}$ & 48 & 9.6 & 13.0 & 10.2 \\
\hline \multirow{3}{*}{ 能 } & 9 & 倉 & 우 & 22 & 7.4 & 11.0 & 8.2 \\
\hline & 10 & 中 & 우 & 44 & 7.6 & 15.0 & 10.2 \\
\hline & 11 & 中 & 全 & 29 & 10.6 & 12.0 & 19.0 \\
\hline \multirow[t]{2}{*}{ 六 } & 12 & & 우 & 20 & 9.4 & 9.3 & 7.8 \\
\hline & 13 & 友 & o & 20 & 9.0 & 4.1 & 8.5 \\
\hline \multirow{3}{*}{ 進 } & 14 & 佐々木 & $\hat{o}$ & 25 & 7.6 & 10.6 & 9.7 \\
\hline & 15 & & 苂 & 25 & 8.8 & 14.8 & 19.7 \\
\hline & 16 & 藤 ○ & 㑒 & 37 & 10.7 & 19.6 & 15.8 \\
\hline \multirow[t]{9}{*}{ 症 } & 17 & 添 & 芰 & 22 & 13.3 & 11.6 & 12.0 \\
\hline & 18 & 東 & 우 & 45 & 6.4 & 12.8 & 9.8 \\
\hline & 19 & 新 0 & 우 & 21 & 9.2 & 19.4 & 10.6 \\
\hline & 20 & & $\hat{o}$ & 33 & 9.8 & 6.3 & 14.6 \\
\hline & 21 & & 全 & 38 & 9.2 & 9.8 & 21.7 \\
\hline & 22 & & 우 & 30 & 9.0 & 13.9 & 19.0 \\
\hline & 23 & 宍 & 㑒 & 29 & 9.0 & 10.8 & $/$ \\
\hline & 1 & 都 & $\hat{o}$ & 29 & 6.2 & 6.8 & 16.9 \\
\hline & 2 & & 全 & 50 & 6.4 & 6.0 & 16.2 \\
\hline & 3 & 直 & 苂 & 18 & 7.3 & 11.0 & 7.2 \\
\hline \multirow[t]{3}{*}{ 正 } & 4 & 兼 $\bigcirc$ & + & 23 & 6.4 & 6.8 & 12.2 \\
\hline & 5 & 名 & 우 & 24 & 5.6 & 5.9 & 9.2 \\
\hline & 6 & 加 & 昘 & 35 & 4.5 & 9.0 & 20.1 \\
\hline \multirow[t]{3}{*}{ 常 } & 7 & 熊 & 우 & 16 & 6.5 & 2.8 & 6.5 \\
\hline & 8 & 恧 & 全 & 49 & 6.0 & 6.0 & 16.5 \\
\hline & 9 & 藤 & \% & 46 & 4.7 & 14.3 & 8.1 \\
\hline \multirow{4}{*}{ 人 } & 10 & 酒 & 占 & 56 & 5.6 & 8.2 & 12.4 \\
\hline & 11 & 木 & $\ddot{q}$ & 49 & 3.5 & 3.5 & 13.3 \\
\hline & 12 & 佐○木 & 우 & 24 & 5.0 & 5.2 & 6.6 \\
\hline & 13 & 菅 & 우 & 21 & 5.6 & 2.5 & 9.5 \\
\hline \multirow{8}{*}{$\begin{array}{l}\text { 機 } \\
\text { 能 } \\
\text { 低 } \\
\text { 症 }\end{array}$} & 1 & 松 & 1우 & 41 & 1.6 & 2.4 & 2.4 \\
\hline & 2 & 䤿 & 우 & 48 & 3.2 & 2.0 & 8.4 \\
\hline & 3 & 堀 & 우 & 29 & 3.6 & 8.8 & 12.5 \\
\hline & 4 & 白 & 㑒 & 35 & 1.0 & 7.2 & 9.8 \\
\hline & 5 & 西 & $\hat{0}$ & 29 & 1.4 & 9.4 & 8.2 \\
\hline & 6 & 茾 & 우 & 55 & 2.5 & 6.4 & 3.6 \\
\hline & 7 & 水 & 우 & 53 & 1.6 & 5.0 & 1.3 \\
\hline & 8 & 山 & 우 & 34 & 4.4 & $\zeta$ & 5.4 \\
\hline
\end{tabular}

第3図 PBI と17-OHGSとの相関

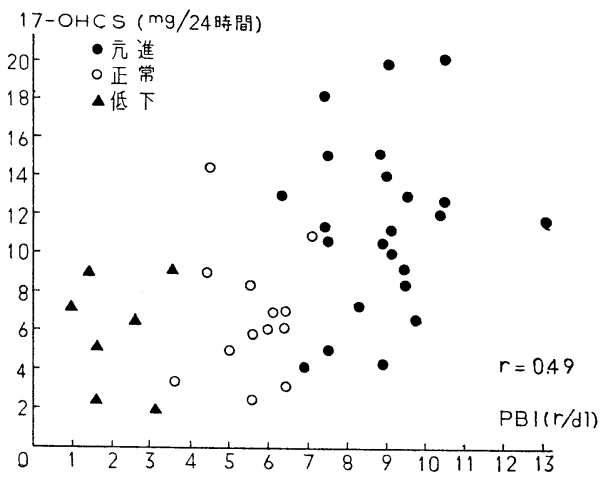

第4図 PBI と17-KSとの相関

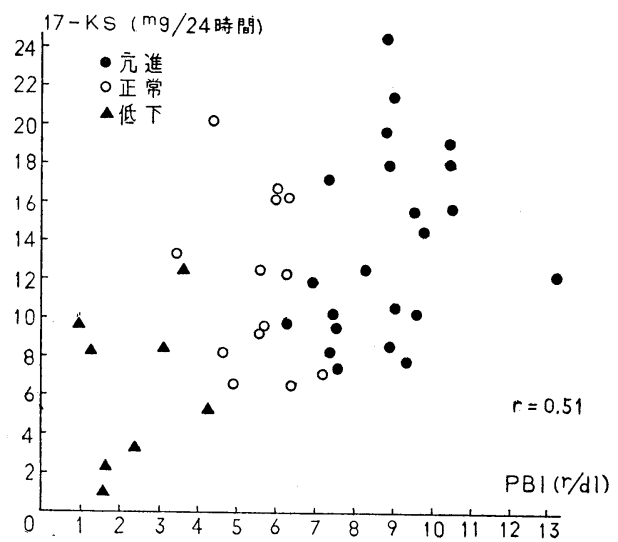




\section{結 果}

\section{1) BMR と 17-OHCSおよび 17-KS}

元進症23例，正常人13例，低下症 8 例，計44例についての BMR と尿中総 17-OHCS および 17-KS，24 時間排泄量の測定值を第 1 表に示した. BMR と 17-OHCS の相関関係は第 1 図の如く，相関係数0.61で推 計学的に有意の正相関を認めた. $(\mathrm{p}<0.01)$ BMR と 17-KS あ第 2 図の如く, 相関係数 0.45 で有意の正相 関を認めた $(\mathrm{P}<0.01)$.

\section{2) $\mathrm{PBI}$ と 17-OHCS および 17KS}

六進症23例，正常人13例，低下症 8 例，計44例の PBI と尿中総 17-OHCS および 17-KS，24 時間排泄 量を第 2 表に示した. PBI と 17-OHCS は第 3 図の如く，相関係数 0.49 で有意の正相関を認訬 $(\mathrm{p}<0.01)$ PBI と 17-KS あまた第 4 図の如く，相関係数0.51で有意の正相関を認めた $(\mathrm{P}<0.01)$.

\section{3) $\mathrm{I}^{131}$ 摂取率と 17-OHCS および 17-KS}

六進症 23 例, 正常人 1 例, 低下症 8 例, 計 32 例の甲状腺 $\mathrm{I}^{131}$ 搷取率 24 時間值と尿中総17-OHCS および17KS 24時間排泄量を第 3 表に示した。 $I^{131}$ 摂取率と 17-OHCS は第 5 図の如く正相関の傾向はみられるが， 相関係数 0.24 で推計学的に有意ではなかつた. しかし $\mathrm{I}^{131}$ 摂取率と $17-\mathrm{KS}$ とは第 6 図の如く，相関係数 0.59で有意の正相関を認めた $(\mathrm{P}<0.01)$. なお $\mathrm{I}^{131}$ 摂取率 3 時間值と 17.OHCS, 17-KS との間にはともに 全く相関関係を認めなかつた。

第 3 表 $\mathrm{I}^{131}$ 摂取率と尿中17-OHCS, 17-KS排泄量

\begin{tabular}{|c|c|c|c|c|c|c|c|}
\hline & 番号 & 被検者 & 性 & \begin{tabular}{l|} 
年 \\
令
\end{tabular} & $\begin{array}{c}\mathrm{I}^{131} \\
\%\end{array}$ & $\begin{array}{c}17-\mathrm{OHCS} \\
\mathrm{mg}\end{array}$ & $\begin{array}{c}17-\mathrm{KS} \\
\mathrm{mg}\end{array}$ \\
\hline \multirow{7}{*}{ 機 } & 1 & 勝 $\bigcirc$ & |ิ & 34 & 30 & 8.3 & 15.5 \\
\hline & 2 & 山 $\bigcirc$ & 우 & 24 & 61 & 4.2 & 11.9 \\
\hline & 3 & 山 $O$ & $\hat{\delta}$ & 44 & 33 & 10.7 & 24.4 \\
\hline & $\begin{array}{l}4 \\
5\end{array}$ & 西 & 우 & 21 & 61 & 5.0 & 7.5 \\
\hline & $\begin{array}{l}5 \\
6\end{array}$ & 古 & 우 & 28 & 25 & 12.5 & 18.2 \\
\hline & $\begin{array}{l}6 \\
7\end{array}$ & 北 & 尔 & 33 & 60 & $\begin{array}{r}18.0 \\
7.2\end{array}$ & 17.2 \\
\hline & 8 & 名 & 定 & 48 & 59 & 13.0 & $\begin{array}{l}12.7 \\
10.2\end{array}$ \\
\hline \multirow{3}{*}{ 能 } & 9 & & 苂 & 22 & 39 & 11.0 & 8.2 \\
\hline & 10 & 中 & $\hat{\beta}$ & 44 & 20 & 15.0 & 10.2 \\
\hline & 11 & & $\hat{\jmath}$ & 29 & 42 & 12.0 & 19.0 \\
\hline \multirow{2}{*}{ 元 } & 12 & & के & 20 & 34 & 9.3 & 7.8 \\
\hline & 13 & & 우 & 20 & 63 & 4.1 & 8.5 \\
\hline \multirow[t]{2}{*}{ 進 } & 14 & 佐○木 & 今人 & 25 & 60 & 10.6 & 9.7 \\
\hline & 15 & 武 & + & $\begin{array}{l}25 \\
27\end{array}$ & $\begin{array}{l}44 \\
57\end{array}$ & $\begin{array}{l}14.8 \\
19.6\end{array}$ & $\begin{array}{l}19.7 \\
15.8\end{array}$ \\
\hline \multirow{7}{*}{ 症 } & 17 & & 우 우 & 22 & 65 & $\begin{array}{l}19.0 \\
11.6\end{array}$ & $\begin{array}{l}15.8 \\
12.0\end{array}$ \\
\hline & 18 & 東 & 오 & 45 & 57 & 12.8 & 9.8 \\
\hline & 19 & 新 0 & 오 & 21 & 68 & 19.4 & 10.6 \\
\hline & 20 & 松 & 今 & 33 & 73 & 6.3 & 14.6 \\
\hline & 21 & נ川 & $\hat{\delta}$ & 38 & 96 & 9.8 & 21.7 \\
\hline & 22 & 伊 & 우 & 30 & 52 & 13.9 & 19.0 \\
\hline & 23 & & $\hat{\delta}$ & 29 & 72 & 10.8 & 1 \\
\hline 正常 & 1 & 下○内 & 占 & 49 & 15 & 6.0 & 16.5 \\
\hline & 1 & & 우 & 41 & 2 & 2.4 & 2.4 \\
\hline & 2 & 0 & 우 & 48 & 37 & 2.0 & 8.4 \\
\hline & 3 & & 우 & 29 & 8 & 8.8 & 12.5 \\
\hline & 4 & & $\hat{\wp}$ & 35 & 21 & 7.2 & 9.8 \\
\hline & 5 & 西 & $\hat{0}$ & 29 & 8 & 9.4 & 8.0 \\
\hline & 6 & 井 & 高 & 55 & 5 & 6.4 & 3.6 \\
\hline & 7 & $\bigcirc$ & 우 & 53 & 5 & 5.0 & 1.3 \\
\hline & 8 & & 果 & $34 \mid$ & 17 & & \\
\hline
\end{tabular}

第 5 図 $\mathrm{I}^{131}$ 摂取率と17-OHCSとの相䦥

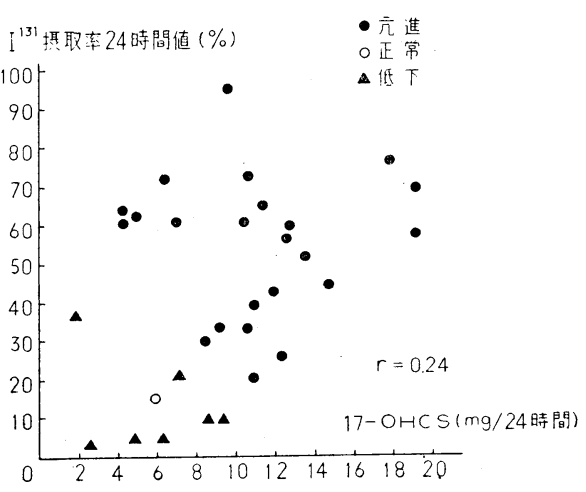

第 6 図 $\mathrm{I}^{131}$ 摂取率と 17-KS との相関

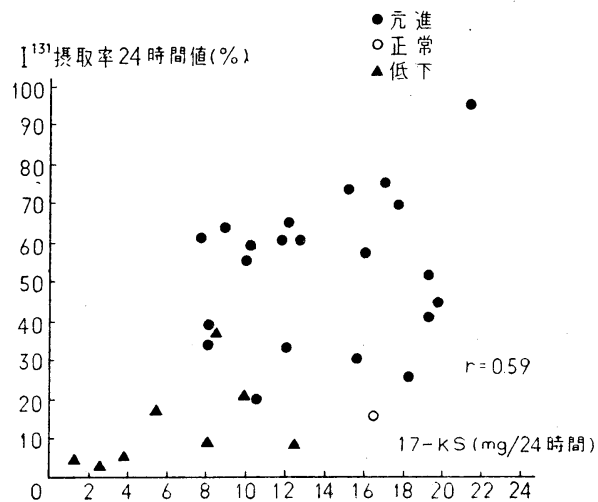




\section{4） ACTH 試験による 17-OHCS および 17-KS の変化}

克進症 21 例，正常人 9 例，低下症 8 例，計 38 例につき ACTH 試験を行い，前日，試験実施当日，翌日の 総 17-OHCS および17-KS の尿中24時間排泄量の測定值を第 4 表に示した。試験実施当日の尿中 17-OHCS 排泄量の平均值は第 7 図の如く，光進症 $25.0 \mathrm{mg}$, 正常人 $25.2 \mathrm{mg}$, 低下症 $23.7 \mathrm{mg}$ で，光進症, 低下症および 正常人との間に有意差はなかつた。試験当日と翌日の17-OHCS 合計量あまた第 8 図の如く，平均值がえ准

第 4 表 ACTH試駼による17-OHCS， 17-KS排泄量の変化

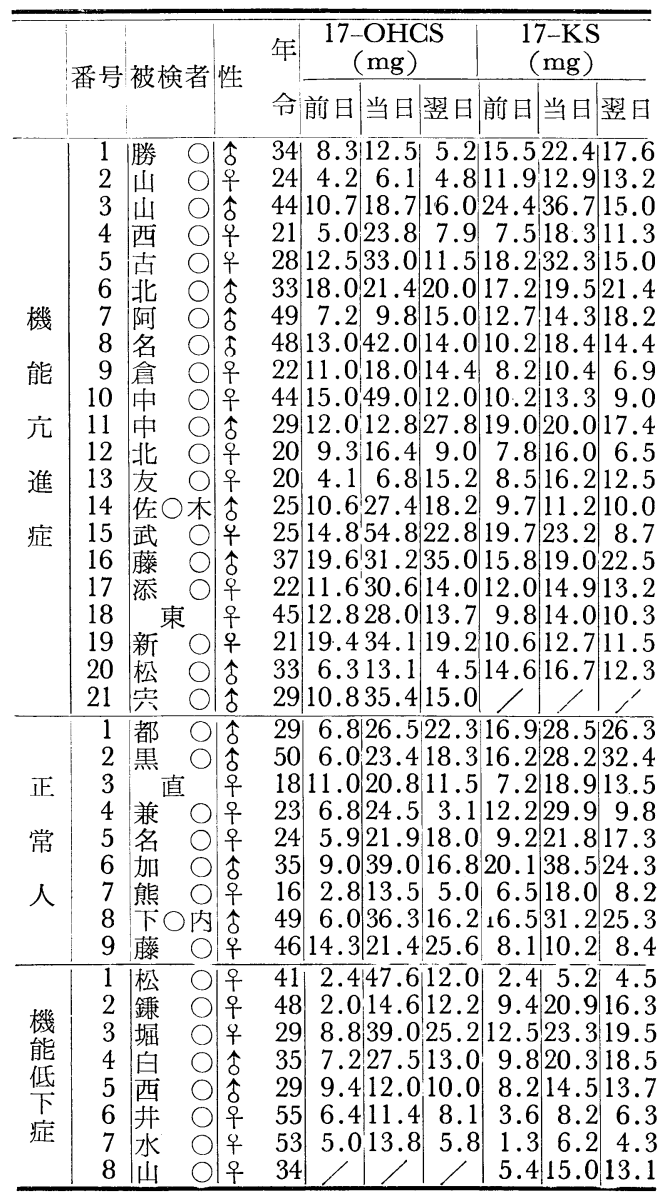

第 7 図試験当日排泄量

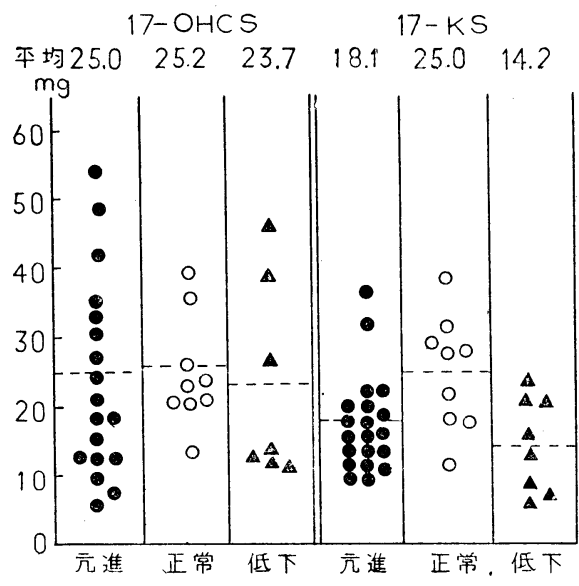

第 8 図当日翌日合計排泄量
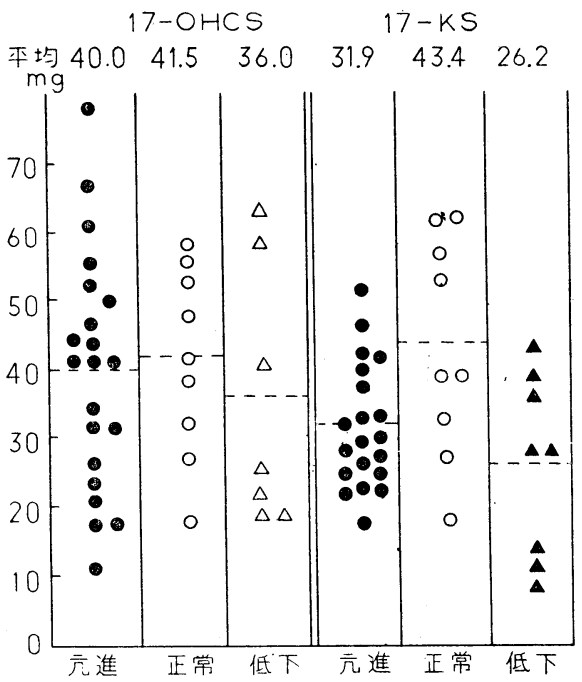

症 $40.0 \mathrm{mg}$ ，正常人 $41.5 \mathrm{mg}$ ，低下症 $36.0 \mathrm{mg}$ で有意差がなかつた。すなわち ACTH 刺㦸による副腎皮質全 分泌能は甲状腺機能の如何によつて有意差が認められなかつた。17-KS は男女とも全体では第 7 図および 第 8 図に示す如く，甲状腺異常者は正常人より屯排泄量は少い $(\mathrm{P}<0.05)$. しかし男女別に分けてしらべる 之，第9図および第10図に示す如く，男性群は甲状腺異常者の排泄量は少いが $(\mathrm{P}<0.01)$ ，女性群では 17OHCS と同様有意差が認められなかつた.

5）好酸球減少率と 17-OHCS および 17-KS

兄進症 21 例，正常人 9 例，低下症 8 例, 計 38 例の ACTH 試験による末梢血液中好酸球減少率之 17-OHCS 


\section{第 9 図 17-KS当日排泄量}

男性群热性群

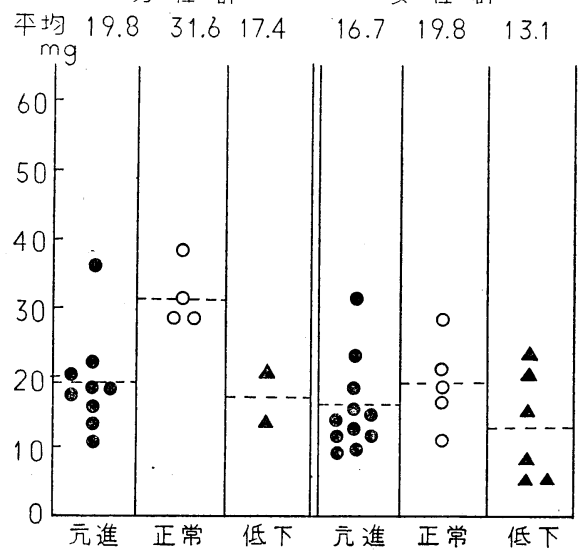

第10図 17-KS合計排泄量

男性群性群

$\begin{array}{llllll}\text { 本均 } 37.4 & 58.5 & 33.5 & 27.5 & 33.2 & 23.8\end{array}$

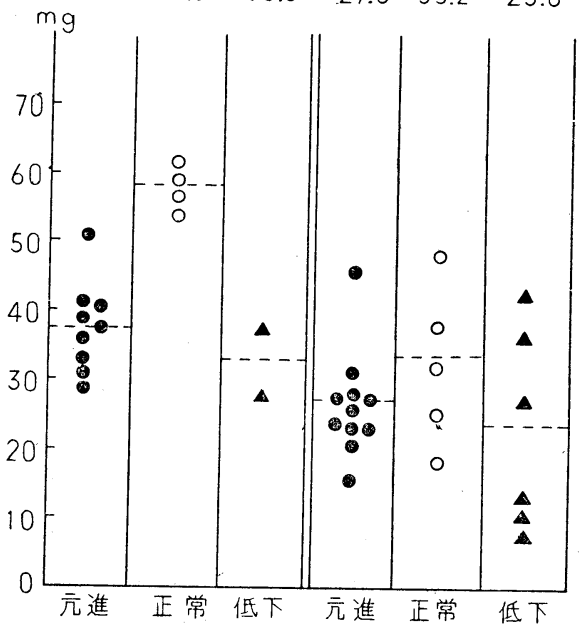

第11図 好酸球減少率とBMRとの相関

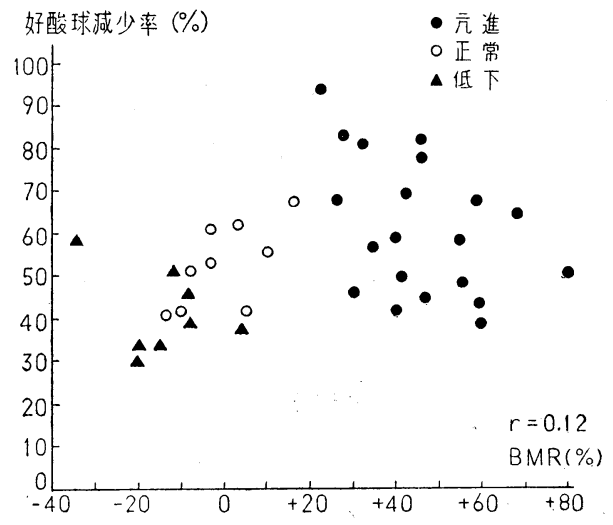

第12図 好酸球減少率とPBIとの相関

好酸球减少晏 $(\%)$

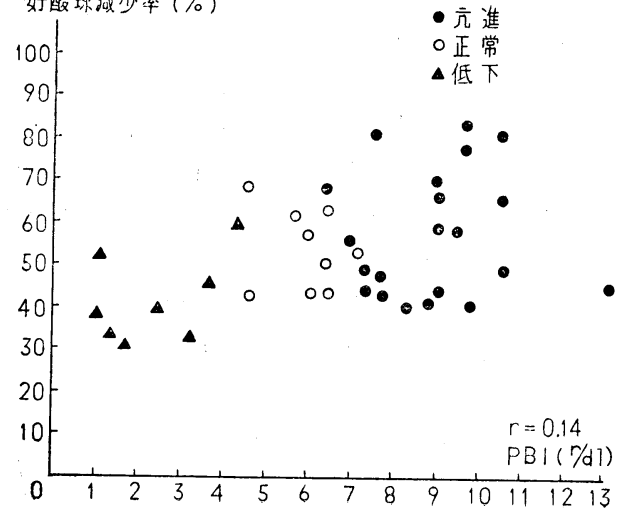


および17-KSとは第11図および第12図に示す如く17-OHCS との相関係数 $0.12 ， 17-\mathrm{KS}$ との相関係数0.14で， 両者と屯に有意の相関関係は認められなかつた。

\section{総括並びに考按}

17-OHCS の代謝について現在次の機転が一般に認もられている ${ }^{40) ~ 42)}$. 副腎皮質から分泌された生物学的 活性の遊離型 17-OHCS は，肝において大部分還元されて Tetrahydro-誘導体となり，グルクロン酸と抱合 され生物学的に不活性の結合型となつて腎より排泄され，一部は遊離型のまま排泄される。

甲状腺疾患における 17-OHCS の研究は1955年 Levin 等 によつて始められた。 彼等は甲状腺機能充進症 患者之低下症患者および正常人に Hydrocortisone を静注し，血中濃度の低下速度が充進症では促進し，低 下症では遅延するのを認めた。すすわち進症においては Hydrocortisone の分解速度が促進し，低下症に おいては分解速度が低下するのであろうと推論した。 その後 Peterson ${ }^{99}$ また静注した Cortisol-4-G ${ }^{14}$ の半娍

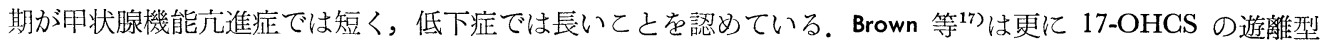
と結合型の変化についての実験を行つた. Cortisol を静注すると血中の遊離型 17-OHCS は血進症で速やか に減少し，低下症で遅延するが，結合型 17-OHCS は克進症では増加し，低下症では減少したと報告してい る. 甲状腺機能宎進症では肝における生物学的変化を促進する多くの酥素が増量しているといわれる。すな わち Lardy ${ }^{49)}$ は甲状腺を投与した動物の肝では多くの酸化酵素の濃度は上昇し，甲状腺剔出動物では低下し ていると述べている. Tomkins ${ }^{44)}$ は甲状腺機能尣進症患者では副腎皮質ステロイドの代謝に関与する多くの酷 素が増量しているといつている. Brown ${ }^{17)}$ は甲状腺機能元進症においては，Cortisol の肝における還元，抱 合機転が促進し，生物学的活性のある遊離型 17-OHCS の血中からの消失が速やかなため，一定の血中濃 度を維持するかめに下垂体前葉の Feed back 作用により副腎からの分泌が増加し，結局尿中総17-OHCS排 沚量が増量し，低下症ではその反対に減少するのであろうと推論している. Peterson むまた同様な見解をむ つている．著者等の検查結果で BMR の上昇，PBI の増加に伴つて，無処宧の基礎状態における尿中 17OHCS 排泄量むまた増加しているのはやはり下重体前葉の Feed back 作用を反映しているものと考えてよ いと思う。

甲状腺 $\mathrm{I}^{131}$ 摂取率24時間值と 17-OHCS 排泄量との間に有意の相関関係はなかつたが， $\mathrm{I}^{131}$ 摂取率の時間 的推移の型が症例により異ることが指摘されており ${ }^{16)}$ ，従つて 24 時間值のみでは有意の相関関係がみられな かつたのではないかと考えられる。

現在副婜皮質ホルモン分必能を定量的に把握するには，ACTH 静脈内点滴注入による血中あるいは尿中 17-CHCS を測定することが最も適切な方法と認められている ${ }^{45) 46}$. 著者等は甲状腺疾患患者々正常人に ACTH 試験を行つて尿中17-OHCS 量を測定したが，克進症，低下症ともに正常人にくらべ，排淮量の平 均值に有意の差を認めなかつた. さきに述べた様に甲状腺機能充進症では肝によるステロイドの還元，抱合 機転の促進のためとこれに伴う下垂体前葉の Feed back 作用によつて㽷中総 17-OHCS 排澌量が増量し， 低下症ではその逆になるが，副腎の ACTH による全分泌能(Capacity) ${ }^{46)}$ は正常人と甲状腺機能異常とで大 差がないといつてよいであろう.

尿中17-KS 排泄量は著者等の測定結果では BMR, PBI に対し 17-OHCS と略々同様の傾向を示した. しかし17-KS は男性においては起源が複雑で性差が大きいので(0)男性群と女性群に分けて尿中 17-KS 排䛧 量と BMR, PBI との相関関係をしらべた，第13図および第14図に示す如く，女性群における 17-KS と BMR との相関係数は $0.46,17-\mathrm{KS}$ とBI との相関係数は 0.65 でともに有意の 正相関関係がある（P< 0.01). しかし男性群においては第15図および第16図に示す如く，17-KS と BMR との相関係数は 0.24 , 17-KS と PBI との相関係数は0.35で有意の相関関係を認めない. また ACTH 試験による男女をあわせた 全体の尿中 17-KS 排泄量は甲状腺異常者は正常人にくらべ低下したが，女性群のみでは有意の差がなかつ た. 女性における 17-KS 排泄量が 17-OHCS と同様の結果を示すととは，さきに述べた著者等の見解を支 持するあのと思われる. 更によく 17-KS の意義を検討するためには 17-KS の分劃測定を行わなければな 
第13図 女性群に打ける17-KS と BMR
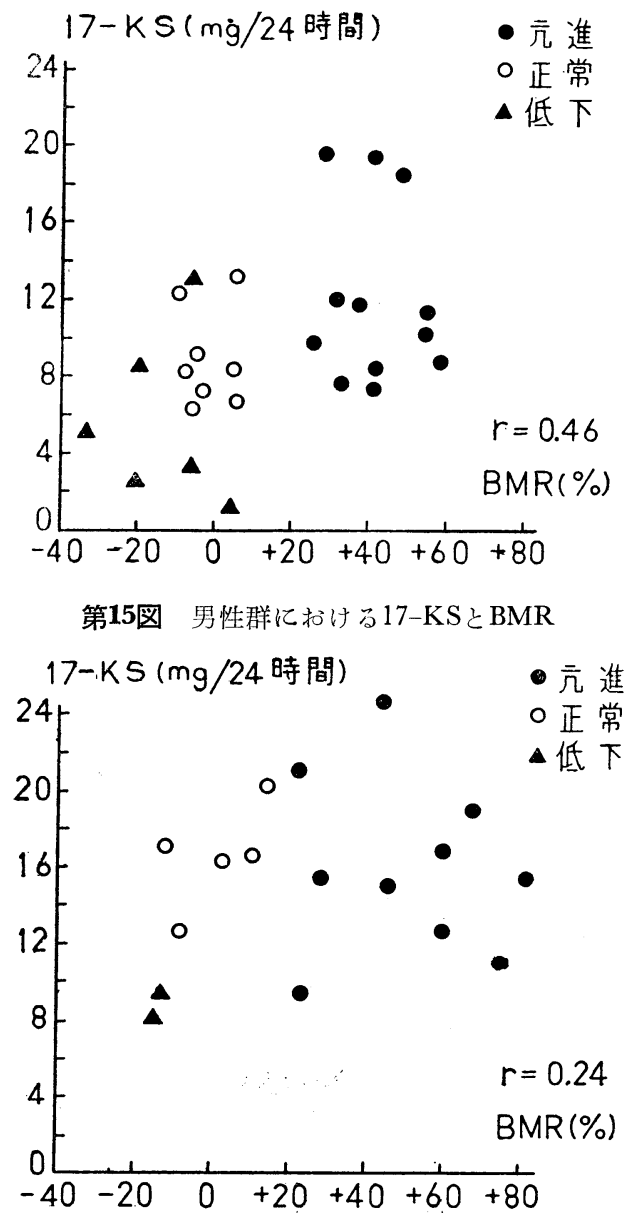

第14図 女性群に打ける17-KSと PBI

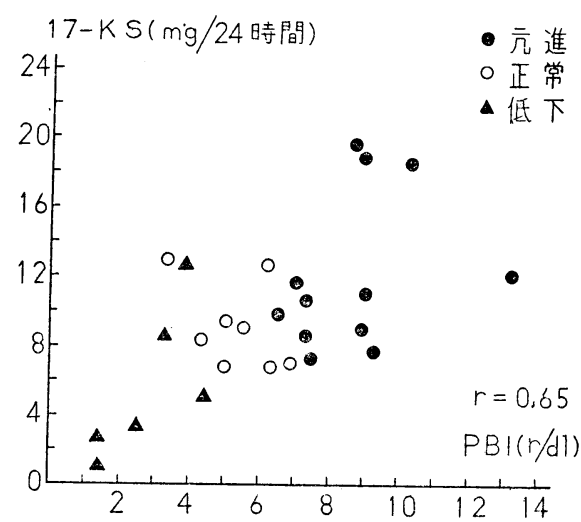

第16図 男性群に扣ける17-KSと PBI

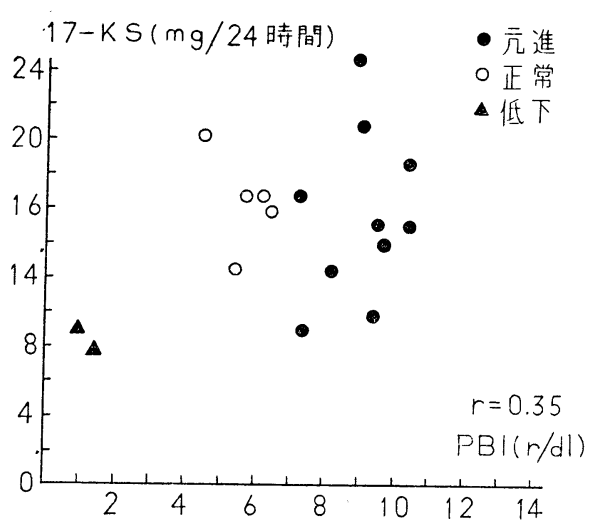

らない.

著者等の検査結果から好酸球減少率と BMR, PBI とは相関関係を認めることができなかつた. しかし最 近では，好酸球減少率は副腎皮質機能を定量的に適切に表現しないという報告が多くみられる. Kelly 等 は ACTH による好酸球の減少は副腎皮質ステロイドの分泌増加のない場合でも起るといつている，Henry 等 ${ }^{48)}$ は好酸球が減少するのは Epinephrine と副腎皮質ホルモンとの協同作用であろうと述べている. Sandberg 等 ${ }^{49}$ は好酸球数は他の種々な因子に影響されるため，副婜皮質機能を常に正しく表現するとは限らない といつている. Ely 等 ${ }^{50)}$ は150例につき ACTH 試験を行い。 副腎皮質ステロイドの反応と好酸球率の間に 全く定量的の相関関係がないととを明らかにし，副䈆皮質機能不全例で ACTH により副腎皮質ステロイド の反応のないにもかかわらず，好酸球数が減少するのを認めた。著者等の測定結果からも，ACTH 試験に おける好酸球減少率と尿中 17-OHCS 排泄量の間に全く相関関係を認めることができなかつた。

以上述べた甲状腺機能と副腎皮質機能との相互関係からその臨床的意義を考えると甲状腺機能九進症が大 きなStress をうけて大量の副婜皮啠ホルモンを要する様な場合，その要求を充分みたすととができないて と屯起り得る。例えば Basedow 氏病手術や甲状腺クリーゼの場合に副腎皮質ホルモンを投与して好成績を あげたことが報告されているが(1) 1821)，乙れは以上の事実を裏書きするものだと考えられる。また粘液水腫 
の患者に副婜皮質ホルモンを投与すると容易に Cushing 症候群を起す可能性がある.

結語

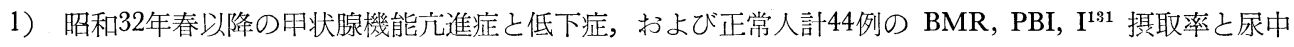
総 17-OHCS, 17-KS 排泄量, ACTH 試験による尿中ステロイドの変化および好酸球減少率を測定した。

2）17-OHCS. 17-KS 排泄量は BMR，PBI と正相関を示したが， I ${ }^{131}$ 摂取率とは 17-KS のみ正相関を 示した。

3) ACTH20単位 6 時間点滴静脈内注入による好酸球娍少率と BMR, PBI は相関関係を認めなかつた。

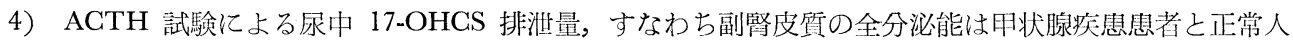
に差を認めなかつた。

終りに御指導御校閱を睗わつた鳥居教授，種々御教示を睗つた佐藤助教授，堀内講師並びに御協力下さつ た教室員各位に深く感謝致します。

(本論文の要旨は第12回東北北海道医師会連合会学術大会, 第32回日本内分泌学会総会，第56回日本内科学 会総会に打いて発表した).

\section{文献}

1) Marin, D. et al. : Ameirc. J. Med. Sci. $180: 767,1930.2$ 2) LeCompte, P.M. et al. : J. Clin. Endocainol. $9: 158,1949 . \quad 3)$ Holst, J. : 2te Internat. Kropfconf. Bern Verhandlgsbericht p.62 Huber, 1935. 4) Means, J.: The thyroid and Its Diseases. p.347 Lippincott, 1948.25 5) Berkheiser, S.W. : J. Clin. Endocrinol. $15: 44,1955 . \quad 6)$ 6evin, M.E. \& Daughaday, W.H. : J. Clin. Endocrinol. \& Met. $15:$ 1499, $1955 . \quad 7$ 7) Perkoff, G.T. et al. : Arch. Int. Med. $93: 1,1954 . \quad$ 8) Wallace, E.Z. : J.Clin. Endocr!nol. \& Met. 14 : 928, $1954 . \quad$ 9) Peterson, R.E. : J. Clin. Invest. 39 : 736, 1958. 10) Beierwaltes, W.H. \& Bishop, R.C. : J.Clin Endocrinol. \& Met. $14: 428,1952 . \quad 11)$ Kenigsberg, S. \& Gavack, T.H. : J. Clin. Endocrinol. \& Met $12: 1551,1952 . \quad 12)$ Fraserl R.H. et al. : Endocrinol. $1: 243,1941 . \quad$ 13) Engstrom, W.W. \& Nelson, H.L. : J. Clin. Endocrinol. $4: 517,1944 . \quad 14)$ Daughady, W.H. et al. : J. Clin. Endocrinols $8: 244,1948.115)$ 鳥飼竜生 : 日本内科学会雑誌，46: 1247，1958. 16）脇坂行一：日本内科学会雑誌， $46: 1262 ， 1958$. 17) Brown, H. et al. : J. Clin. Endocrinol. \& Met. $[8: 167,1958 . \quad 18)$ Shapiro, S. \& Marine, D. : Endocrinology $5: 699$, 1921. 19) Rawson, R.W. \& Rall, J.E. : Duncan's Diseases of Metabolism p.1007 Saunders 1952. 20) Szilagy, D.E. et al. : Ann. Surg. $136: 555,1952 . \quad 21)$ Rukes, J.M. et al. : Metabolism $3: 481,1954$. 22) Mikulai, L. \& Nemet, S. : Schweiz. Med. Wochenshr. $88: 384,1958 . \quad 23)$ Money, W.H. : The Thyroid, Brookhaeven Sympos. Biol. No.7 p.137, 1954.24$)$ Hoskins, R.G. : J.A.M.A. $55: 1742$, 1910. 25) Lowenstein, B.E. \& Zwemer, R.L. : Endocrinology $30: 1035,1942 . \quad 26)$ Deane, H.W. \& Greep, ${ }_{2}^{r}$ R.O. : Endocrinology $\left.41: 243,1947 . \quad 27\right)$ Zarrow, M.X. \& Money, W.L. : Endocrinology 5 : 699, 1921. 28) Hill, S.R. et al. : J. Clin. Endocrinol. $10: 1375,1950 . \quad 29)$ Wolfson, C.T. \& Eya, M. : J Lab. \& Clin. Med. $36: 1005,1950.30$ 30) Money, W..H. et al. : Endocrinology $48: 682$, 1951. 31) Barker, S.B. \& Humphrey, M.J. : J. Clin. Endocrinol. $10: 1136,1950 . \quad 32$ 日置陸 奥男: ホルモン化学検查法, P.122, 南江堂, 1956. 33) 山下久雄 : アイソトープ医学応用技術, P.110，地人書館，1956. 34) Thorn, G.W. : J.A.M.A. 137 : 1005, 1948.25$)$ Reddy, W.J. Metabolism $3: 489,1954 . \quad 37)$ Forscham, P.H. : Personal communication. 38) Renold,A.E. et al. : J. Clin. Invest. $31: 675,1952 . \quad 39)$ Renold, A.E. et al. : J. Glin. Endocrinol. \& Met. $12: 763$, 1952. 40) Forsham, P.H. \& Thorn, G.W. : Williams's Textbook of Endocrinology p.231 Saunders 1955. 41) Sameels, L.T. \& West, C.D. : Vitamins \& Hormones $10: 251,1952.4$ 42) Petersan, 
R.E. et al. : J. Clin. Invest. $36: 1301,1957 . \quad 43)$ Lardy, H. : The Thyroid, Brookhaeven Sympso. Biol. No.7, p.137, 1954. $\quad 44)$ Tomkins, G.M. : Rec. Prog. Hormone Res. 12 : 125, 1956. Thorn, G.W. et al. : J. Glin. Endocrinol. \& Met. $13: 604,1953 . \quad 46)$ Eik-Nes, K. et al : J. Clin. Invest. 33 : 1502, $1954 . \quad$ 47) Kelly, V.C. e.t al. : Proc. Soc. Exper. Biol. \& Met. 81:611. 1952. 48) Henry, W.L. et al. : Americ. J. Physiol. $174: 475,1953 . \quad 49)$ Sandberg, A.A. et al.: J. Clin. Endocrinol. \& Met, $13: 629,1953 . \quad 50)$ Ely, R.S. et al. : J. Clin. Invest. $33: 1587,1954$. 